\title{
Ownership Structures
}

\section{Ownership Structures for Stability and Control}

When founded, the vast majority of the companies in the sample (26 out of 36) were launched as single ownership entities using a variety of legal formats, from single proprietorships to incorporated stockholding companies. Over time, as the initial founders passed away, all of these firms eventually migrated into other forms of ownership, mostly involving groups of investors or successor families.

Of the remaining ten firms, eight were founded as different forms of partnerships, or groups of owners getting together to jointly own a firm. Again, most of these firms, after some time of operating in a partnership format, experienced that one or the other of the partners ended up shouldering the total responsibility, buying out the other interests. Over time, these firms also changed their ownership structures into a series of different formats, ranging from family companies to public ownership. Two of the ten were founded as family companies from the outset. They involved two generations of ownership from the beginning and remained family-owned to this day.

The desire to control the companies through stable ownership was a central theme in the interviews with current owners or managers. There was an overriding concern that if a company was sold, the core of its operations might be dissipated, or that new owners might not have the same interest as the previous generation in maintaining the company in its present format. This should not be interpreted as being opposed to any ownership change at all. Rather, owners carefully planned any changes, if possible, and wanted to be intimately and personally involved in the selection of new owners who would continue the tradition of the company. 


\section{From Single Ownership to Family Company}

There is a natural and inherent risk in a change of ownership once the founder steps down or passes away. Of the 26 firms founded as single ownerships, 13 companies managed to preserve majority ownership through the founders' descendants. Of those companies moving to other ownership forms, four of them were acquired by private investor groups, seven became public firms, and three were transitioned to new corporate ownership structures; for example, they were acquired by other firms and thus ceased their legal independence while continuing to operate.

Given that independence was viewed as a guarantee for survival over the long term, how then did the firms who preserved ownership manage to maintain this status, in some cases over several generations? The chosen strategies were invariably impacted by company circumstances, as well as by the capital market options available at the time of generational change. The following five examples represent long-lasting firms, founded more than 100 years ago, in addition to some that were founded more recently. The details published here can also be followed in the company profiles devoted to the 36 companies at the end of this book.

\section{Family Ownership for the Long Term}

Few companies can look back on a more storied history than Sefar. Founder Pierre Dufour (1799-1842), originally from Lyon, France, started his gauze silk weaving business in Thal, located in the St. Gallen Rhine Valley, in 1833, under the name of Dufour \& Cie. When he died suddenly, after returning from a business trip to the United States, it was his widow who took charge to keep the business in the family:

At the time of her husband's death, Anna Joséphine Dufour-Onofrio (1817-1901), had been married for two just years and was left with their infant son barely one year old. Although Mrs. Dufour, now a single mother of 25, who had moved two years earlier from Lyon to Thal and shown a strong interest in her husband's business, was nevertheless expected to return to Lyon with her son Antoine (1841-1889). However, Mrs. Dufour remained in the small village of Thal and assumed management of the company employing about 50 home-based weavers and, presumably, a similar number of employees for preparing the yarn, shipping and general office work. At the 1855 World Exhibition in Paris, Dufour-Gauze was awarded the first-class silver medal. But "Madame Dufour," as she was typically called, not only possessed exceptional entrepreneurial and commercial skills, but was also active in the local women's association, had a hospital built and enabled a workers' support and pension fund.

When Mrs. Dufour realized that her son did not show sufficient enthusiasm for the business, she actively began to groom a potential successor. Christoph Tobler (1838-1907), son of a local farmer, had joined the company in 1855 as an apprentice. Joséphine Dufour appreciated the bright, diligent and eloquent young man and entrusted him with more and more managerial tasks. In 1872, when a partner retired from the company, Christoph Tobler received a share in the profits and in 1890, after the death of Antoine Dufour, he became a co-owner of Dufour \& Co. His brother, August Tobler (1884-1906), also became a managing director and co-owner. While Christoph Tobler traveled the world in search of new customer contacts, August Tobler worked in the company in Thal. Christoph Tobler had 16 children of whom five held senior positions in the company. In 1901, when Joséphine 
Dufour-Onofrio died at the age of 84 , the Toblers had become co-owners of the company then employing around 1000 people. The company continued to operate as Dufour \& Co. for several decades until merging into Sefar in $1995 .{ }^{1}$

Additional detail about how Sefar remained in family ownership over the decades are included at the end of this chapter.

As had happened to the Sefar family, the founder of Kuhn Rikon died just a few years after the company was founded. Having left the business to his widow and two teenage sons, who were willing to enter the business under the guidance of the family, family ownership of the company was thus extended for decades.

When Kuhn Rikon founder Heinrich Kuhn died in 1932 at the age of 55 of a brain tumor he left his business to be managed to his two teenage sons, Henri age 18 and Jacques age 14. The business had grown to include some 50 employees. His wife inherited ownership, which was later transferred in equal proportion to her two sons, Henri and Jacques. The elder son Henri died early in 1969 at the age of 55, passing on his 50 percent stake to his wife (25 percent), and the other 25 percent in equal shares to his four children.

The situation was different with the 50 percent ownership of Jacques Kuhn (1918-2017) who did not marry until very late in his life and did not have any children. He bequeathed his 50 percent stake in the form of a pre-inheritance to Henri's daughter Rosanne, who married Wolfgang Auwärter, later to become CEO of Kuhn Rikon. Combining her two inheritance stakes led to majority ownership for the Auwärter-Kuhn branch of the family. When Auwärter stepped down from the board, his daughter Dorothee Auwärter, a lawyer by training, assumed the position of board chairwoman. "You must have somebody with a clear majority" believed Wolfgang Auwärter. ${ }^{2}$

\section{Owned by the Same Family Over Multiple Generations}

Successive generations of Geistlich family members retained ownership of the company and were also actively involved in its governance, thus keeping the business in family hands for 150 years.

Heinrich Geistlich founded his bone processing company in 1851 near Zurich. Upon his death, his son Eduard Geistlich took over in 1864. Eduard's sons transformed the company in 1909 into a shareholding company with shares owned by Geistlich family members. Over its entire history, Geistlich remained a private company owned by Geistlich family members and their descendants. The Geistlich shareholding group comprised about 40 family members with a shareholder agreement in place. The group met for a general assembly once per year. Since the retirement of Peter Geistlich, no Geistlich family member was active in operational management. Both boards, for the holding company and for Geistlich Pharma, included Geistlich family members, with the present chairman, Andreas Geistlich, nephew of Dr. Peter Geistlich (1927-2014) who had acted as the prime mover of getting Geistlich into the field of bio regeneration. The company owners were committed to a strategy of independence. $^{3}$

\footnotetext{
${ }^{1}$ Adapted from Sefar company profile.

${ }^{2}$ Adapted from Kuhn Rikon company profile.

${ }^{3}$ Adapted from Geistlich company profile.
} 


\section{The Effort to Keep the Business Within the Family}

As already witnessed, the death of the business founder challenges the owning family to find a suitable succession while still keeping the business in family control. At Plaston, this was only possible by inviting some non-family investors to join while keeping majority ownership in the family.

Plaston founder Hans Frei founded his business in 1956 at the age of 55. A first generational change took place in 1973 with the retirement of the founder who had seven children. Hans passed away in 1977, and his son Roland took over management. Roland became CEO and ran the company until 1999.

Until 1990, Plaston remained entirely family-owned. The strategic objective was to restrict shareholding to those who would or could have a direct influence on the company's future success. As a result, it was decided to purchase the shares of the four sisters of Roland Frei. The newly available shares, representing 35 percent of the capital, were then re-sold to seven members of management acquiring 5 percent each. This move was designed to strengthen awareness around the mutual goals of keeping Plaston on the road to success.

In 2004, Roland Frei needed to repurchase shares owned by management. To obtain the necessary funds, Plaston decided to go public and to list its shares on the secondary market. The Frei Family still held over 54\% of the shares, with the rest held by management and a small group of outside investors. In 2013, Roland Frei's son, Jörg, became chairman of the Plaston Board, thus representing the third generation of the Frei family at the helm of the company. ${ }^{4}$

\section{How Two Families Preserved Combined Ownership for the Next Generation}

When several families engage in a business together, it becomes an even greater challenge to keep the business in the family and to pass it on to the next generations. At Sylvac, the owning families managed to do just that while changing the ownership shares at the same time.

Sylvac, started in 1973 by Hans Meyer developing electronic modules for two local firms. Schnyder \& Cie was founded by the younger Urs Schnyder in 1969 as a producer of delicate precision modules supplied to Sylvac and its customers. The two families were indirectly related through marriage and had known each other for a long time. The close collaboration of Sylvac SA as development and sales arm, and Schnyder \& Cie as the manufacturing arm, continued for about 25 years to their mutual benefit. Sales increased steadily, from about CHF 2 million in 1989 to CHF 20 million in 1998. It weathered changes in management, when the sons of Urs Schnyder, Eric and Jacques, joined that business, and at Sylvac, when management passed to Daniel Liechti, son-in-law of founder Hans Meyer and brother-in-law of Hans-Ulrich Meyer, son of the founder.

The founders of the two companies wanted to make sure that the future was in the hands of their 2nd and 3rd generation and in 2006 decided to merge both companies into a single entity under the Sylvac name. The transfer of ownership took place at reasonable share prices such that the Schnyder family, with Eric and Jacques, were able to acquire the

\footnotetext{
${ }^{4}$ Adapted from Plaston company profile.
} 
majority of the shares, with the remainder of the capital in the hands of the Meyer and Liechti families. Jean-Noël Liechti, son of former CEO Daniel Liechti, joined the company to head the IT department. Eric Schnyder assumed the role of CEO and his brother Jacques Schnyder headed manufacturing at Malleray. ${ }^{5}$

\section{Passing Ownership from One Family to Another Family}

The history of Fraisa is an example of the circumstances under which a family is not able to remain an active owner and, if possible, finds a new owner who is willing to continue the tradition and legacy of the founding family. This may, perhaps, be the best solution to that specific problem.

Fraisa founder Hans Stüdeli started a tool making business in Bellach (SO) in 1934. When he passed away unexpectedly in 1950, his son Hans assumed ownership control and management of the firm. He remained in control for almost 40 years until retiring at 75 . He turned over the company and ownership to his two daughters and their families, the Schibli-Stüdeli and the Fröhlicher-Stüdeli families. While the two daughters were loyal to the business, neither had a technical background. At the age of 84, Hans Stïdeli convinced the family to sell the company to the CEO, Josef Maushart, who had been with the firm for many years. With the Maushart family acquiring control of Fraisa, ownership passed into the hands of a second family who had an interest to continue to run the business as a family company. The Stüdeli families allowed this to happen through internal financing and an earn-out based on company cashflow. The transfer of ownership took place in 2005 and the descendants of the Stüdeli family continued to serve on the Fraisa board together with representatives of the Maushart family. ${ }^{6}$

\section{Passing Ownership Through a Succession of Three Different Families}

What happened at Fraisa once also occurred at Acutronic twice. Each time the new Acutronic owners treated the business as a family company and took care that the next owners would do the same.

Since Leo Marxer founded Acutronic in 1973, the company had always been a family company. In 1996, Thomas W. Jung, at the age of 30, bought the company from Leo Marxer. Thomas Jung had a family business background and had previously worked for DaimlerChrysler Aerospace in Munich. Partly for family reasons, and because he was attracted by the challenge to run his own business, he decided to move back to Switzerland and buy the financially distressed company. The takeover was largely financed by money from his family.

In 2015, after almost 20 years with Acutronic, Jung sold the company to the Aigrain family due to the lack of a potential successor within his family. Thomas W. Jung could have sold the company to a private equity fund or to a corporate owner, but he preferred to keep the company in private hands. Because of the private ownership, management enjoyed

\footnotetext{
${ }^{5}$ Adapted from Sylvac company profile.

${ }^{6}$ Adapted from Fraisa company profile.
} 
greater independence than as a public company. By selling the company to private owners, Jung explicitly tried to preserve the strategic focus and identity of the company. ${ }^{7}$

\section{Going Public to Assure Succession}

At Bachem, founder Peter Grogg did not have any family members willing to step in to run the company. By resorting to an IPO, he was able to attract and keep professional management while maintaining controlling ownership for his family.

Peter Grogg founded his company Bachem in 1971 to serve the growing market for chemicals used in pharmaceutical research processes. Privately held by Grogg, Bachem was listed on the Swiss stock exchange in 1998 when the company had reached CHF 100 million in revenue. The founder retained about 60 percent of the shares. Reasons for the IPO were largely private. For once, there were no family members prepared to enter into an operative role at the company. In addition, founder Grogg was said to always have had an interest to run a publicly held company after having successfully started a privately held firm.

Top management, who had always been granted shares by Grogg, experienced real value for their holdings as a result of the IPO. To avoid any "short-termism," senior management indicated that a company needed anchor shareholders committed over the long term. Founder Grogg with his controlling stake in the company clearly fit that stabilizing role. Grogg retired from the board in 2011 to become Honorary Chairman. The board was now chaired by an outside Chairman, with Grogg's daughter in the role of vice-chair. ${ }^{8}$

Opening ownership to external shareholders offered the benefit of bringing in additional capital to grow the enterprise. By maintaining majority control, the founding families and descendants of the company founders let external investors participate financially in the success of the companies while maintaining their ability to lead the business in the ways that they always had. Listing the shares on secondary exchanges also allowed for some shadow pricing of the ownership stakes, creating an internal market for some of the family owners who decided to sell part or all of their stakes. This financial flexibility combined with continued ownership control was often cited in interviews as a strong motivation to pursue broadening the ownership base.

\section{Employing Shareholder Agreements to Provide Stability}

Since almost all companies transferred to stockholding structures as their owners retired or passed away, the preferred method of maintaining control within a closeknit group or family was the shareholding agreement. Many companies used this mechanism to force transactions within the family. A special case was Sefar that evolved through several mergers to become a family-owned company involving nine

\footnotetext{
${ }^{7}$ Adapted from Acutronic company profile.

${ }^{8}$ Adapted from Bachem company profile.
} 
different families. Their process of ensuring long-term family control survived the test of time:

Sefar resulted from a merger of several companies in 1995. The founding families, including the Dufour and the Tobler families, remained owners of Sefar AG. Overall, there were nine families, each owning between 3 and 20 percent of the company. There were transfer restrictions in place and shares could only be sold to members of one of the nine families. The tradability of the shares was ensured via an informal "stock exchange" at a bank. Selected top managers of the company could become shareowners, with their shares reverting to the founding families after their death. In 2018, less than 10 percent of the company was not family-owned. ${ }^{9}$

Similar arrangements were maintained by the three owner families of Caran d'Ache where the Hübscher, Reiser, and Christin families dominated the shareholding group, with the Hübscher family being in the 4th generation of majority owner. The descendants of Emil Richterich, founder of Ricola, remained the only shareholders of Ricola, now chaired by the 3rd generation, with a 4th generation entering the business as well. Such practices of signing shareholder agreements were common for many of the SMEs studied.

\section{Assuming Founding Partner Stakes to Provide Stability}

Of the nine companies documented that started as some form of partnership between two or more entrepreneurs, only Caran d'Ache survived as a partnership between its three owner-families. All other companies changed into alternative ownership structures, from reverting to single ownership, becoming a public firm, or being acquired by corporate owners. Buying out a partner presented a delicate task that could cause difficulties. Both EAO and LNS serve as examples of how to accomplish this successfully.

EAO founders Kurt Loosli (1921-1988) and René Thalmann (1921-1993), two schoolfriends, combined their efforts and resources and founded EAO in Olten in 1947, sharing ownership on an equal basis. When co-founder Kurt Loosli passed away in 1988, his widow Dora Loosli inherited the 50 percent stake in the company. In 1993, co-founder René Thalmann died, again leaving his widow to inherit a 50 percent stake. The two widows and their families were confronted with what to do about the company. The Thalmann family decided they wanted sell, the Loosli family decided to stay in the business. Rather than one family buying the other out, the two families settled on an asset split. To make this work, the Thalmann family took all non-core business assets ranging from the real estate and excess liquidity. The Loosli family ended up with the direct business assets but very little liquidity which initially made the running of the divided business difficult. ${ }^{10}$

\footnotetext{
${ }^{9}$ Adapted from Sefar company profile.

${ }^{10}$ Adapted from EAO company profile.
} 
At LNS, which was started by three partners, ownership evolved over time so that only one of the three owner families remained.

André Léchot, one of the three original LNS founders, owned a small workshop in Orvin. For his cousin, he developed a solution for feeding metal bars automatically into turning machines. Léchot enlisted two friends for the commercialization of his solution. First was Walter Neukomm, a tool maker working for Tornos, a large CNC turning machine manufacturer. He brought the industrial manufacturing knowledge to the project. Second, Léchot pulled in Maurice Scemama, owner of a machine tool shop and a gifted salesman selling specialty machine tools and tools to watch industry suppliers. The mechanical genius (André Léchot), Mr. Industrialization (Walter Neukomm), and the consummate salesman (Maurice Scemama) joined to form LNS in 1972 with the purpose of commercializing the automatic bar feeding opportunity.

The company commenced operation in 1973, Walter Neukomm was its first CEO until his sudden death in 1979. LNS remained a privately owned company with Co-founder Maurice Scemama as board chairman. In 1987, Maurice Scemama's two sons, Philippe and Yves Scemama, started working for LNS, and Yves assumed the role of CEO in 1995. Ownership control had remained in the Scemama family and was shared between the two brothers and their sister. ${ }^{11}$

\section{MBOs to Recruit New Owners}

When the interest of founder-owners or descendants in a company waned, the danger increased that a business would go into decline or be sold to corporate or financial owners. When ownership could not assure continued talent to lead, managers within the company may be best placed to guarantee continuation. Existing management was usually familiar with the firm, its technology, and the business environment. External owners, new to all of this, might not bring the necessary understanding. Thus, a number of the documented companies have gone the route of promoting managers to owners and give that management shareholder's rights. This can range from minority stakes all the way to transferring controlling stakes. Such was the path taken by the owners of Filtrox.

When Hans Schmid, founder and owner of Filtrox, passed away in 1948, just ten years after starting the company, ownership passed to a number of families from the St. Gallen region. However, none of the families had a deep interest in the filtration business and left the company's fate in the hands of management. In 1990, Toni Rusch, who had joined the company a few years earlier and headed Filtrox management, had a chance to buy a significant stake from one of these families and become a shareholder. Later, his son Cristian Rusch became CEO of the company. The Rusch family and three other families remained investors, all with a long-term perspective and an interest to preserve the company's independence. $^{12}$

\footnotetext{
${ }^{11}$ Adapted from LNS company profile.

${ }^{12}$ Adapted from Filtrox company profile.
} 
A rather different approach was chosen by Urs Baumann at Lantal when he was confronted with the challenge of finding a successor outside of his family.

Urs Baumann's grandfather Friedrich Baumann had started a weaving business in Langenthal in 1886. Urs Baumann's father, Willy Baumann, had separated from that family business in 1951 to create an upholstery weaving business, eventually called Lantal. When Urs Baumann wanted to step down from leading Lantal in 2003, he found that none of his family members wanted to continue in active management. Urs Baumann hired a headhunter to find a new manager and, maybe, possible successor for his business. They settled on Urs Rickenbacher who had a background in the furniture business and who, together with some members of management, took over the ownership of the Lantal company through an MBO in 2004. Rickenbacher and his team have led the company ever since, assuring continuity of the business. ${ }^{13}$

At Burckhardt Compression, an MBO initiated by company management led to independence from corporate ownership.

Burckhardt Compression could look back on a varied history traversing several ownership formats, from single ownership to subsidiary as part of Sulzer Group. In 2000, a pivotal time for the Sulzer Group, Valentin Vogt was appointed to head Sulzer-Burckhardt. During this period, Sulzer Group decided to focus on four business areas only. Sulzer-Burckhardt and three other business areas were put up for sale.

Vogt and his team concluded a deal with a private equity firm who acquired 78 percent of the shares in the process. The management team kicked in 20 percent of equity and made a deal with Sulzer to acquire the business for CHF 54 million. Vogt was convinced that, once out of the corporate umbrella, where "every management hierarchy costs 2 to 3 percent in EBIT," they would be able to manage on their own far better than being part of a large corporation. As part of the move to separate from the Sulzer Group, the company name was changed to Burckhardt Compression. ${ }^{14}$

\section{Reflections on Ownership Models}

No single ownership model appeared to dominate. Rather, different firms adopted different models and they appeared to succeed at their chosen model. Surprisingly, a large number of companies migrated from single ownership to family ownership as a result of succession, staying with the family ownership model over extended periods of time. Geistlich and Sefar are the outstanding examples of this practice. Other companies remained family-owned, but the owning family changed over time. Fraisa serves as an example here. Several other companies migrated from one ownership model to another over time, sometimes even reverting to earlier models. Examples of this particular evolution are Burckhardt Compression and Sécheron. This was sometimes influenced by a new generation of owners, particularly when the new owners were not part of the founder's family.

\footnotetext{
${ }^{13}$ Adapted from Lantal company profile.

${ }^{14}$ Adapted from Burckhardt Compression company profile.
} 
Ownership and providing effective control over the future of the company was of paramount importance to the leadership of all of the companies documented in this research project. Despite the common goal of effective control, the forms of ownership varied widely across the group of firms with various companies taking different routes to get there. Some of the pathways were imposed through fate or history while others were chosen freely. In general, each company leadership appeared satisfied with its chosen ownership model while harboring doubts about the models adopted by others. From the perspective of the other companies, the feeling was often mutual! Whichever ownership model was adopted, the crucial element was that it be implemented carefully and executed faithfully. How this was done in order to provide stability is the focus of the next chapter.

Open Access This chapter is licensed under the terms of the Creative Commons Attribution 4.0 International License (http://creativecommons.org/licenses/by/4.0/), which permits use, sharing, adaptation, distribution and reproduction in any medium or format, as long as you give appropriate credit to the original author(s) and the source, provide a link to the Creative Commons license and indicate if changes were made.

The images or other third party material in this chapter are included in the chapter's Creative Commons license, unless indicated otherwise in a credit line to the material. If material is not included in the chapter's Creative Commons license and your intended use is not permitted by statutory regulation or exceeds the permitted use, you will need to obtain permission directly from the copyright holder.

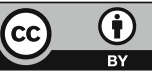

